\title{
How many people on our planet eat insects: 2 billion?
}

\author{
A. van Huis ${ }^{1 *}$, A. Halloran ${ }^{2,3}$, J. Van Itterbeeck ${ }^{4}$, H. Klunder ${ }^{5}$ and P. Vantomme ${ }^{6}$ \\ ${ }^{1}$ Laboratory of Entomology, Wageningen University E Research, P.O. Box 16, 6700 AA Wageningen, the Netherlands; \\ ${ }^{2}$ Department of Nutrition, Exercise and Sports, Faculty of Science, University of Copenhagen, Denmark; ${ }^{3}$ GLOBE Institute, \\ Center for Macroecology, Evolution and Climate, Faculty of Health and Medical Sciences, University of Copenhagen, Denmark; \\ ${ }^{4}$ Centre for Asian Area Studies, Rikkyo University, 3-34-1 Nishi-Ikebukuro, Toshima, 171-8501 Tokyo, Japan; ${ }^{5}$ In2Care BV, \\ Marijkeweg 22, 6709 PG Wageningen, the Netherlands; ${ }^{6}$ Retired senior FAO expert; editor-in-chief@insectsasfoodandfeed.com
}

(c) 2021 Wageningen Academic Publishers

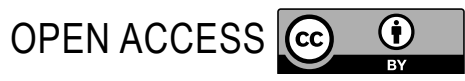

\section{EDITORIAL}

\begin{abstract}
The estimated figure of two billion people consuming insects mentioned in the 2013 FAO/WUR report about edible insects has been cited many times over. This editorial asks four questions to determine the accuracy of the estimated figure: how to define an 'insect-eating' person; which percentage of the population eats insects; how does insect consumption develop over time; and how to define an edible insect? Our conclusion is that it is difficult to establish an exact figure of how many people eat insects globally and that the much cited 2 billion figure in the FAO/WUR report must be an overestimation.
\end{abstract}

\section{Introduction}

The FAO report 'Edible insects: future prospects for food and feed security' (Van Huis et al., 2013) received tremendous attention from the scientific community and in the popular press (Vantomme, 2017). Often, the figure of two billion people eating insects on our planet has been cited from the report (Page 1). However, we would like to revisit this and ask whether this figure is correct. The figure refers to the traditional consumption of harvested insects mostly by people from tropical countries. We have tried to check where this figure in the report came from. Apparently, it was introduced by one of the authors referring to a non-scientific publication, which we could not trace back to its source. However, without putting a judgement on this figure, let us try to look at it in more detail.

What needs to be considered, when actually addressing the question of how many people on our planet eat insects? In general, there are no statistics available. The Food and Agriculture Organization (FAO) does not collect data on insect consumption. In their FAOSTAT database covering over 245 countries and territories, information relating to nutrition, food and agriculture is collected, analysed, interpreted, and disseminated, though not on edible insect consumption, production or trade. Also, at national and subnational levels, statistics on edible insects are often absent.
When it comes to other commodities, rice for example, more precise historical data are collected by governments and available in all kinds of reports, such as: total volume produced and traded, per capita consumption, the number of rice-producing nations, the contribution to total global calorie supply, and contribution to rural livelihoods. However, even for rice it is a challenge to find out how many people consume this commodity. One report mentioned 3.5 billion people who depended on rice for more than $20 \%$ of their daily calories (GRiSP, 2010: 6), yet this figure cannot be found in their extensive Rice Almanac (GRiSP, 2013).

When estimating the total global population that consumes insects, the following considerations should be made:

- When do we consider a person 'insect-eating'?

- What percentage of a national population eats insects?

- How does insect consumption change over time?

- What is considered a consumed edible insect?

We will discuss these different questions in the following chapters.

\section{When do we consider a person 'insect-eating'?}

This question has to do with the frequency of insect consumption. Using the case of rice consumption again, its contribution can be measured as the percentage of total 
dietary energy provided. This went from about 10\%, both in Latin America and Africa, to about 30\% in Asia (FAO, 2021). While insects are not necessarily considered staple food sources like rice, wheat or maize, consuming an insect on occasion should not necessarily classify an individual as 'insect-eating.'

If somebody ate insects as a child and stopped once they reached adulthood, should we consider such a person 'insect-eating'? Probably not. If a person consumes insects as an occasional snack maybe once or twice a year, do we consider that person 'insect-eating'? Also, probably not. Traditionally, wild insects have been consumed when the opportunity arises, due to, for example, the swarming of reproductive termites with the first rains after the dry season, or the appearance of caterpillars during a particular season. Seasonality therefore plays an important role in the availability of wild edible insect species. However, as in the case of Thailand, different edible insect species may be available across seasons, enabling individuals and sub-populations to consume insects year round in some cases (Yhoung-Aree and Viwatpanich, 2005); while in Lao People's Democratic Republic, some insect species can be harvested throughout the year, such as Macrotermes spp. soldiers or the giant water beetle, Lethocerus indicus (Hanboonsong and Durst, 2014).

The growth of insect farming can also contribute to the availability of edible insects. However, the growth of this sector is still limited and cannot yet be attributed to having a significant effect on the frequency and volume of consumption.

\section{What percentage of a national population eats insects?}

To address this question, we will consider only the consumption of harvested insects and not the recent development of farming insects for food and feed. Considering Australia and North America, insects have only been consumed traditionally by some indigenous groups (Shockley et al., 2018; Yen, 2005), while in Europe it is absent except in a handful of cultures (e.g. casu marzu in Sardinia). Edible insect consumption on the other continents - Asia, Africa and Latin America - will be discussed below.

\section{Asia}

If countries where insects are eaten are considered in the estimation of the total global population that consumes insects, then China and India would qualify. This would indicate that one third of the global population (i.e. 2.8 billion out of 7.8 billion people) consumes insects. However, this does not seem to be a fair calculation as we know that some sub-populations do not eat insects, while others do.
Having data on a national level or sub-national level would help to estimate the accuracy of the total national population that consumes insects. But do such data exist? For India, Gahukar (2018) mentions a number of states where tribal communities eat insects. If we calculate the number of inhabitants of those states, then they together (about 390 million) represent $32 \%$ of the total population of India (Wikipedia, 2021). However, is it possible to consider the total population within these states as part of a tribal community? It is very likely that this is not the case, so the figure should be much lower. In China also, only a part of the population eats insects. For example, Feng et al. (2020) mention a number of states where silkworm and diving beetles are eaten. We often know approximately how many species are consumed and in which regions of a country, but this does not always help us to calculate precisely the population that consumes insects.

However, without any doubt there are parts of a country where insects are eaten frequently. During a field trip by two of the authors to a village in the Democratic Republic of Lao in 2008, just north of Vientiane, many different insect species were being harvested and consumed, and at the local market numerous insect species were being sold. Also in Thailand, a variety of insect species could be found at local markets (Durst and Hanboonsong, 2015).

\section{Africa}

There are some data from Africa on insect consumption. However, these surveys are often not representative of the total population in a country. In Oyo state in Nigeria when young people were interviewed about insect consumption, $45 \%$ of the respondents ate insects in the past but not anymore, while another $25 \%$ still did (Ibitoye et al., 2021). In southern Cameroon $87 \%$ of the population mentioned grasshoppers as food (Ngoute et al., 2021). In the Central African Republic, an estimated 95\% of the people dwelling in forest areas ate caterpillars, but in other areas only $80 \%$ of the population did (N'Gasse, 2004), while in the Democratic Republic of Congo (DR Congo), 70\% of the respondents ate caterpillars (Mapunzu, 2004). In the province of Kasai in the southwest of the DR Congo 28\% ate insects (an average of $2.4 \mathrm{~kg} /$ month) (Kitsa, 1989) - some insects like palm weevils were available throughout the year but other kinds of insects such as caterpillars and termites were only seasonal. Two ethnic groups in the Congo basin ate termites throughout the year (up to $32 \%$ of days in a certain month); while for the caterpillars, this went up to $72 \%$ of the days in a certain month (Takeda and Sato, 1993). In the DR Congo, 10\% of consumed animal-source protein was estimated to be derived from insects (Gomez et al., 1961). In Malawi, 86\% of the people in Lilongwe City and several rural villages in Mzimba district consumed termites and another 68\%, $46 \%, 17 \%$ consumed caterpillars, grasshoppers, and lake flies, respectively (Mikkola, 1997). 


\section{Latin America}

In Latin America, approximately 50 million people (about $10 \%$ of the total population) are indigenous peoples. Insects contributed significantly to the food security of the majority of the autochthonous societies in the northwest Amazon (5 to $7 \%$ of total protein intake during the year and $12-26 \%$ during certain months of the year) (Costa-Neto, 2016). The same study found that urban populations in Latin America despised insect consumption and associated it with poverty.

\section{How does insect consumption change over time?}

A general observation is that the traditional consumption of harvested insects is declining over time. This is mainly due to nutrition transitions that occur because of economic and social development. During an interview about edible insects by one of the authors (Van Huis, 2003) a teacher of crop protection in Niger mentioned, 'I ate insects before, but since having achieved a certain standard of living, insects are no longer a part of our diet.' This has to do with the status of insects as a 'poor man's diet'. Yen (2010) indicated that aboriginals were eating fewer insects over time due to increased adoption of European diets. Ibitoye et al. (2021) concluded from Nigeria that there was a steady decline in the number of young people that consumed edible insects.

In some instances, some culturally important edible insect species are becoming harder to find due to deforestation, land use change, climate change and overexploitation, such as in Malawi (Maseko et al., 2017) and Mexico (RamosElorduy, 2006).

\section{What is considered a consumed edible insect?}

Insects may be consumed intentionally or unintentionally, and they may also be used for different purposes than food. In southeast Asia, for example, insect tea refers to teas made from leaves bitten by insects, and the droppings of insects that feed on specific plants (Feng et al., 2020). The red dye of food products such as carmine (cochineal), with the scientific formula E120, is used in many types of food (Farooq, 2017). But can these two examples be considered 'consumed edible insects'? We should probably only consider the harvested insects that are prepared, conserved, and often eaten, ground or whole, and are destined to be an intentional part of a meal or snack. What about the insects that are eaten unintentionally? Extraneous matter such as insect fragments found in processed food products like orange juice or ketchup are permissible to a certain extent and regulated by national food safety authorities (Berenbaum, 1995: 177; Yen, 2016).

\section{Conclusion}

With the lack of statistics on edible insects, it is almost impossible to calculate an accurate figure of how many people eat insects globally. Determining such a figure depends heavily on the criteria mentioned above. To consider a person as an 'insect-eater', their consumption should be at least one insect species during a part of the year. In countries that are labelled as insect-eating, it is most likely a sub-set of the total population. In addition, it appears that the consumption of harvested insects is declining. Therefore, the two billion figure in the FAO/ WUR report seems to be an overestimation. But the figure of several hundreds of millions could be possible.

Of course, it is unclear how insect farming will develop in the coming years. It may be that with insects being promoted as a healthy and sustainable food source insect consumption will increase in the future. Paradoxically, this trend seems to start in temperate zones, where there is no tradition of eating insects. However, insect farming may also, eventually, reverse the trend of declining insect consumption in tropical and sub-tropical countries.

\section{References}

Berenbaum, M.R., 1995. Bugs in the system. Helix books, AddisonWesley Publishing Company, Reading, United Kingdom.

Costa-Neto, E.M., 2016. Edible insects in Latin America: old challenges, new opportunities. Journal of Insects as Food and Feed 2: 1-2. https://doi.org/10.3920/JIFF2016.x001

Durst, P.B. and Hanboonsong, Y., 2015. Small-scale production of edible insects for enhanced food security and rural livelihoods: experience from Thailand and Lao People's Democratic Republic. Journal of Insects as Food and Feed 1: 25-31. https://doi.org/10.3920/ JIFF2014.0019

FAO, 2021. Rice and human nutrition. Food and agriculture Organization of the United Nations, Rome, Italy. Available at: https://www.fao.org/RICE2004/en/f-sheet/factsheet3.pdf.

Farooq, Y., 2017. Carmine (E120): a study on its legal and juridical status. Journal of Religious Studies 1: 1-10. https://doi.org/10.33195/ uochjrs-v1iI442017

Feng, Y., Zhao, M., Ding, W.F. and Chen, X.M., 2020. Overview of edible insect resources and common species utilisation in China. Journal of Insects as Food and Feed 6: 13-25. https://doi.org/10.3920/ JIFF2019.0022

Gahukar, R.T., 2018. Entomophagy for nutritional security in India: potential and promotion. Current Science 115: 1078-1084. https:// doi.org/10.18520/cs/v115/i6/1078-1084

Gomez, P.A., Halut, R. and Collin, A., 1961. Production de protéines animales au Congo. Bulletin Agricole du Congo 52: 689-700.

GRiSP, 2010. CGIAR Thematic Area 3: Sustainable crop productivity increase for global food security. Global Rice Science Partnership (GRiSP). Proposal for a CGIAR Research Program on Rice-Based Production Systems (September 2010). Available at: https://cgspace. cgiar.org/rest/bitstreams/125590/retrieve. 
GRiSP, 2013. Rice almanac, $4^{\text {th }}$ edition. GRiSP (Global Rice Science Partnership), International Rice Research Institute, Los Baños, Philippines. 283 pp. Available at: http://books.irri. org/9789712203008_content.pdf.

Hanboonsong, Y. and Durst, P.B., 2014. Edible insects in Lao PDR: building on tradition to enhance food security. Food and Agriculture Organization of the United Nations. Regional Office for Asia and The Pacific, Bangkok, Thailand. Rap Publication 2014/12. Available at: https://www.fao.org/3/i3749e/i3749e.pdf.

Ibitoye, O., Oyetunji, P., Kolejo, T., Ogundele, O. and Gabriel, A., 2021. Patterns of consumption of edible insects among young people in three local government areas in Oyo state, Nigeria. International Journal of Tropical Insect Science 41: 2185-2189. https://doi. org/10.1007/s42690-020-00304-7

Kitsa, K., 1989. Contribution des insectes comestibles a l'amélioration de la ration alimentaire au Kasaï-Occidental. Zaire-Afrique 29: 511-519.

Mapunzu, M., 2004. République démocratique du Congo: Contribution de l'exploitation des chenilles et autres larves comestibles dans la lutte contre l'insécurité alimentaire et la pauvreté en République démocratique du Congo. Available at: https://www.fao.org/3/j3463f/ j3463f06.htm\#5.

Maseko, H., Shackleton, C.M., Nagoli, J. and Pullanikkatil, D., 2017. Children and wild foods in the context of deforestation in rural Malawi. Human Ecology 45: 795-807. https://doi.org/10.1007/ s10745-017-9956-8

Mikkola, H., 1997. The use of wild foods in Malawi. The Society of Malawi Journal 50(2): 40-53. http://www.jstor.org/stable/29778981

N'Gasse, G., 2004. République centrafricaine: contribution des chenilles/larves comestibles à la réduction de l'insécurité alimentaire en République centrafricaine. Available at: https://www.fao.org/3/ j34.63f/j3463f06.htm\#4.

Ngoute, O.C., Hunter, D. and Lecoq, M., 2021. Perception and knowledge of grasshoppers among indigenous communities in tropical forest areas of southern Cameroon: ecosystem conservation, food security, and health. Journal of Orthoptera Research 30: 117130. https://doi.org/10.3897/jor.30.64266

Ramos-Elorduy, J., 2006. Threatened edible insects in Hidalgo, Mexico and some measures to preserve them. Journal of Ethnobiology and Ethnomedicine 2: 51. https://doi.org/10.1186/1746-4269-2-51
Shockley, M., Lesnik, J., Allen, R.N. and Muñoz, A.F., 2018. Edible insects and their uses in north America; past, present and future. In: Halloran, A., Flore, R., Vantomme, P. and Roos, N. (eds) Edible insects in sustainable food systems. Springer International Publishing, Cham, Switzerland, pp. 55-79. https://doi.org/10.1007/978-3-31974011-9_4

Takeda, J. and Sato, H., 1993. Multiple subsistence strategies and protein resources of horticulturists in the Zaire basin: the Nganda and the Boyela. In: Hladik, C.M., Hladik, A., Linares, O.F., Pagezy, H., Semple, A. and Hadley, M. (eds) Tropical forests, people and food: biocultural interactions and applications to development, UNESCO, Man and the Biosphere Series: V. 13, pp. 497-504.

Van Huis, A., 2003. Insects as food in sub-Saharan Africa. Insect Science and its Application. 23: 163-185. https://doi.org/10.1017/ S1742758400023572

Van Huis, A., Itterbeeck, J.V., Klunder, H., Mertens, E., Halloran, A., Muir, G. and Vantomme, P., 2013. Edible insects: future prospects for food and feed security. FAO Forestry Paper 171. Rome, Food and Agriculture Organization of the United Nations, Rome, Itatly and Wageningen University and Research Centre, Wageningen, the Netherlands. 187 pp. Available at: https://www.fao.org/3/i3253e/ i3253e.pdf.

Vantomme, P., 2017. Creating an enabling environment. Chapter 20. In: Van Huis, A. and Tomberlin, J.K. (eds) Insects as food and feed: from production to consumption. Wageningen Academic Publishers, Wageningen, the Netherlands, pp. 381-397.

Wikipedia, 2021. List of states and union territories of India by population. Available at Wikipedia: https://en.wikipedia.org/wiki/ List_of_states_and_union_territories_of_India_by_population.

Yen, A., 2016. Them and us: Dining on insects. Wildlife Australia 53: 45-47.

Yen, A.L., 2005. Insects and other invertebrate foods of the Australian aborigines. In: Paoletti, M.G. (ed.) Ecological implications of minilivestock: potential of insects, rodents, frogs and snails. Science Publishers, Inc., Enfield, NH, USA, pp. 367-388.

Yen, A.L., 2010. Edible insects and other invertebrates in Australia: future prospects, FAO, Regional Office for Asia and the Pacific, Bangkok, Thailand. Available at: https://www.fao.org/3/i1380e/ I1380e01.pdf.

Yhoung-Aree, J. and Viwatpanich, K., 2005. Edible insects in the Laos PDR, Myanmar, Thailand, and Vietnam. In: Paoletti, M.G. (ed.) Ecological implications of minilivestock: potential of insects, rodents, frogs and snails. Science Publishers, Inc., Enfield, NH, USA, pp. 415-440. 